\title{
AN EXPERIMENTAL STUDY ON FLEXURAL BEHAVIOR OF PROSOPIS JULIFLORA ASH CONCRETE
}

\author{
GOVINDASAMI. S
}

Professor \& Head, Department of Civil Engineering

Vel Tech High Tech Dr Rangarajan Dr Sakunthala Engineering College, Chennai, India

MONISH RAJ. N. R

Assistant Professor, Department of Civil Engineering

Vel Tech High Tech Dr Rangarajan Dr Sakunthala Engineering College, Chennai, India.

\section{ANJU. M S}

Assistant Professor, Department of Civil Engineering

Vel Tech High Tech Dr Rangarajan Dr Sakunthala Engineering College, Chennai, India

\section{ELAIYA BHARATHI. E}

Structural Engineering

Vel Tech High Tech Dr Rangarajan Dr Sakunthala Engineering College, Chennai, India

\begin{abstract}
This study is on partial replacement of cement by Prosopis juliflora (also known as seemai karuvel in local areas) and its characteristic behavior in concrete. The juliflora powder of 2.5\%, 5.0\%, 7.5\% \& 10\% used to replace cement by weight and M 30 concrete was prepared. The investigation include casting of specimens for each proportions to obtain its compressive strength, split tensile strength by testing cylindrical concrete specimen of standard size and flexure behavior by prism of size $100 \mathrm{~mm} \times 100 \mathrm{~mm} \times 500 \mathrm{~mm}$. The test results were compared with the strength of nominal concrete. On testing the compressive strength the concrete with $2.5 \%$ juliflora was found to be efficient of $133 \%$. The split tensile strength on testing the cylindrical concrete specimen was found to be $3.5 \mathrm{MPa}$ with $2.5 \%$ julliflora. Testing of prism provided the flexural strength of $6.64 \mathrm{MPa}$. It was concluded that replacing $2.5 \%$ of cement by juliflora powder may reduce the cost of construction by saving the cement.
\end{abstract}

Keywords: Ash concrete, compressive strength, flexural Strength, prospis juliflora, tesnsile strength 
Cite this Article: Govindasami. S, Monish Raj. N. R, Anju. M S and Elaiya Bharathi. E, An Experimental Study on Flexural Behavior of Prosopis Juliflora Ash Concrete, International Journal of Civil Engineering and Technology, 11(4), 2020, pp. 54-60.

https://iaeme.com/Home/issue/IJCIET?Volume $=11 \&$ Issue $=4$

\section{INTRODUCTION}

Prosopis juliflora inflorescence is small, green-yellowish spikes without any particular fragrance or attractiveness, though relished by bees. Prosopis juliflora is one of these species that has performed much better than many native woody species. At the moment, prosopis juliflora provides approximately $75 \%$ of fuel wood needs of rural people in arid and semi arid regions of India. These species has become naturalized and spread over the greater part of north-west, central, west and south India. Prosopis juliflora is xerophytes and is adapted to many soil types under a wide range of moisture conditions. Prosopis juliflora has been used to arrest wind erosion and stabilize sand dunes on coastal areas. It is fast growing, nitrogen-fixing and tolerant to arid conditions and saline soils. Under the right conditions, Prosopis juliflora can produce a variety of valuable goods and services: construction materials, charcoal, soil conservation and rehabilitation of degraded and saline soils. But wide spread prosopis juliflora has became an invader species, so removal of the plant is into necessity now. Mostly the plant is removed by uprooting and is burnt. Utilization of waste material like wood ash, fly ash, coconut shell ash are used for partial replacement of cement in concrete to minimize the environmental and ecological problems [1,2,3,4,5]. Researchers carried out experiments on preparing economical concrete using prosopis juliflora, wood ash, fly ash and $\mathrm{M}$ sand $[6,7,8,9,10]$. The aim this investigation is to minimize the cost of construction. An experimental investigation was carried out on concrete containing waste prosopis juliflora ash in different percentages and partially replacing the cement.The properties (compressive, split tensile and flexural strength) were determined at different curing periods and compared with conventional M30 concrete.

\section{MATERIALS \& METHODS}

\subsection{Specimens}

M30 grade concrete was used in casting all the specimens. The cube of size $150 \mathrm{~mm} \times 150 \mathrm{~mm}$ $\mathrm{x} 150 \mathrm{~mm}$ and specimens were casted to determine the compressive strength at 28 days as per the standard IS procedures for all replacement percentages of flyash. Similarly, the prismatic beam specimens of size $500 \mathrm{~mm} \times 150 \mathrm{~mm} \times 150 \mathrm{~mm}$ have been casted, and tested at 28 days, as per the standard IS procedures.Curing of specimens have been done with water for 28 days.

\subsection{Materials used}

Ordinary Portland Cement (OPC) of 53 Grade has been used. Locally available river sand passing through $4.75 \mathrm{~mm}$ IS sieve was used as fine aggregate conforming to the requirements of IS 383-1970.The river sand was washed and screened for dust particles and to eliminate waste materials and oversized particles.Coarse aggregate used was locally available material, crushed angular aggregate and passing through sieve size $20 \mathrm{~mm}$. Potable water has been used for concrete and curing purposes.

\subsection{Partial Replacement}

Wood ashwas prepared from the uncontrolled burning of the wood (prosopis juliflora).The specific gravity of wood ash was found to be less than of cement. Specific gravity of wood ash 
is 2.12 conforming of BS 5628-2005.The suitable range of specific gravity of wood is 1.6 to 2.8. The juliflora ash shown in Fig.1

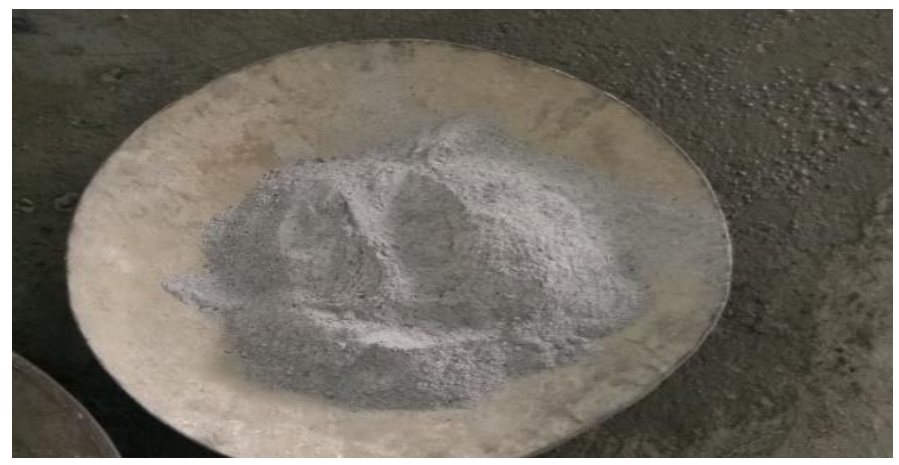

Figure 1 Juliflora ash

\subsection{Physical Properties of Materials}

The specific gravity of prosopis juliflora ash and aggregates used in this study are given in Table 1.

Table 1 Physical properties of materials

\begin{tabular}{|c|c|c|c|}
\hline Properties & Fine Aggregate & $\begin{array}{c}\text { Coarse } \\
\text { Aggregate }\end{array}$ & Prosopis juliflora Ash \\
\hline Specific gravity & 2.66 & 2.68 & 2.12 \\
\hline
\end{tabular}

\section{RESULTS \& DISCUSSION}

\subsection{Compressive Strength}

The compressive strength of concrete was done at 28 days as per the Indian Standards for different percentage of juliflora (JF) and the equipment is shown in the Fig 2.. Compressive strength for JF-2.5\%, JF-5.0\%, JF-7.5\% and JF-10.\% are given in Table 2 .

Table 2 Compressive sternght of concrete

\begin{tabular}{|c|c|c|c|}
\hline Juliflora (JF) & \% of juliflora & Comp. Strength (N/sq.mm) & Percentage of increase \\
\hline JF-0 & $0.0 \%$ & 34 & 0 \\
\hline JF-2.5 & $2.5 \%$ & 45.5 & $133 \%$ \\
\hline JF-5.0 & $5.0 \%$ & 34 & $100 \%$ \\
\hline JF-7.5 & $7.5 \%$ & 34.4 & $101 \%$ \\
\hline JF-10.0 & $10.0 \%$ & 26.22 & $77 \%$ \\
\hline
\end{tabular}

From the Table 2 it was found that there is increase in the compressive strength of concrete with increase in replacement of juliflora material in cement concrete [6]. The data shows that there is increase of upto $134 \%$ in comparison with the nominal concrete i.e. concrete with zero replacement of juliflora. On further replacement of the material with the cement is leading to decrease in the strength to $100 \%, 101 \%$ and $77 \%$ for JF-5.0,JF-7.5 and JF-10.0 respectivley. 


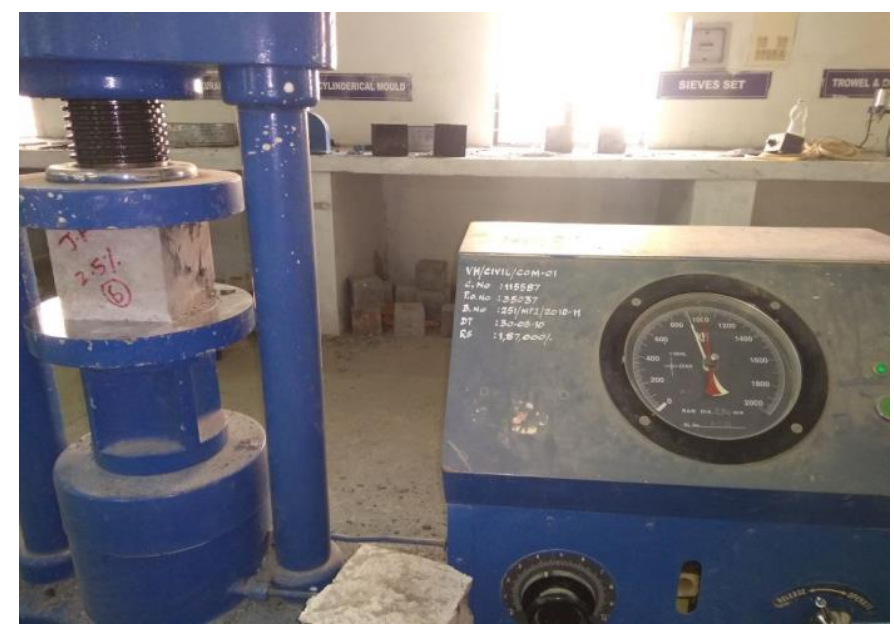

Figure 2 Compressive strength testing machine

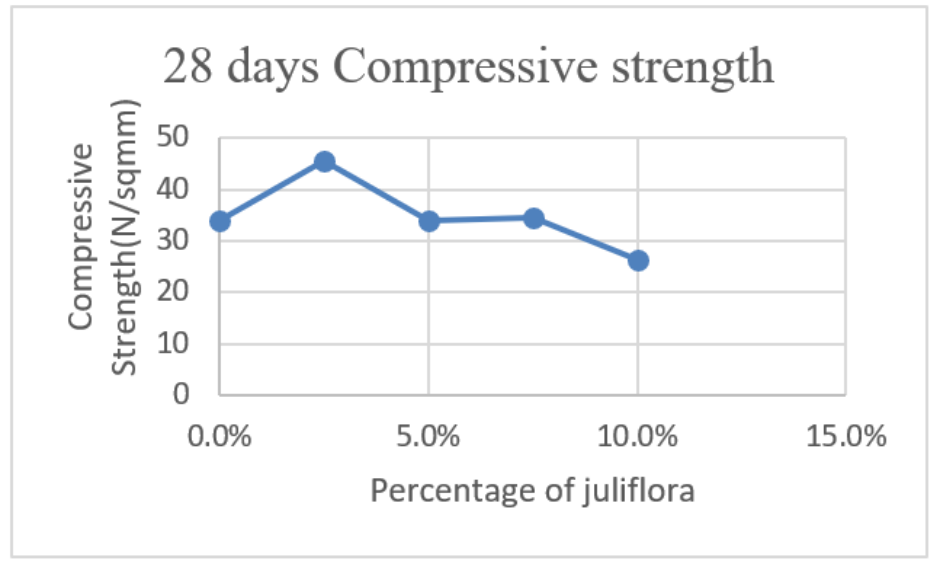

Figure 3 Compressive strength of concrete

Fig 3 shows the 28 days compressive strength and there is a clear increase on slope from $0 \%$ to $2.5 \%$ of replacement and then there is greadual decrease in the strength inferring that the replacement of $2.5 \%$ of juliflora is found to be more effeicent with cement in concrete .

\subsection{Split tensile Strength}

The split tensile strength was carried out in a standard size cylinder of $150 \mathrm{~mm}$ diameter with $300 \mathrm{~mm}$ height and shown in Fig 4. The load was applied on the specimen at UTM and the required formula was adapted to determine the tensile strength of concrete.

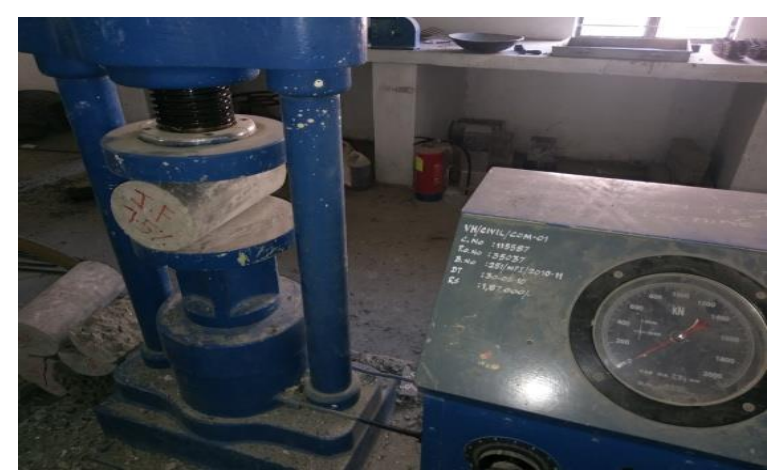

Figure 4 Split tensile strength of cylindrical concrete 
The split tensile strength is given in the Table 3.

Table 3 Split tensile sternght of concrete

\begin{tabular}{|c|c|c|c|}
\hline Juliflora & Mix Ratio & Split tensile strength & \% of increase \\
\hline JF-0 & $0.0 \%$ & 2.56 & $0 \%$ \\
\hline JF-2.5 & $2.5 \%$ & 3.5 & $137 \%$ \\
\hline JF-5.0 & $5.0 \%$ & 2.9 & $113 \%$ \\
\hline JF-7.5 & $7.5 \%$ & 3.2 & $125 \%$ \\
\hline JF-10.0 & $10.0 \%$ & 2.24 & $88 \%$ \\
\hline
\end{tabular}

From the Table 3 it was found that there is increase in the split tensile strength of concrete with replacement of juliflora in place of cement. There is a increase and decrease in strength by $137 \%, 113 \%, 125 \%$ and $88 \%$ with respect to the nominal concrete [6]. An optimum increase took place in the strength of concrete with $2.5 \%$ of replacement of juliflora for cement.

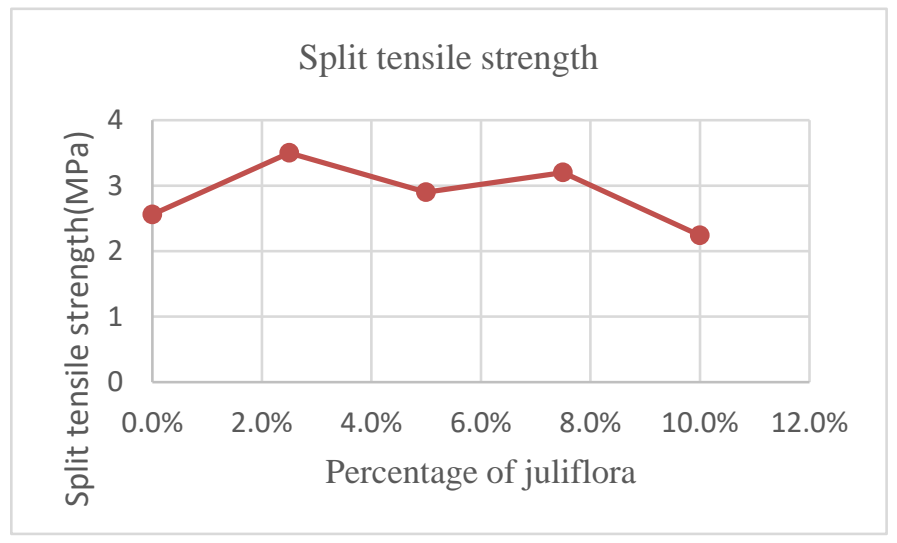

Figure 5 Split tensile strength of cylinder concrete

Fig 5 shows that there is a gradual increase in the strength of concrete with $2.5 \%$ of replacement of juliflora and on further addition there is a decrease in concrete strength. Thus it is inferred that $2.5 \%$ replacement provide an efficient strength in concrete $[6,8]$.

\subsection{Flexural Strength}

The flexural strength of the concrete was done as per IS-516-1959 for the specimen size of 100 $\mathrm{mm} \times 100 \mathrm{~mm} \times 500 \mathrm{~mm}$ and the load was applied to the speciem of 28-days curing with four point loading to determine the flexural behavior of the replaced juliflora concrete.

The flexural strength was tested over the computerized UTM shown in Fig 6with accuracy of $0.01 \mathrm{kN}$ reading. The two roller support is provided and the specimen is tested for its flexural behavior.

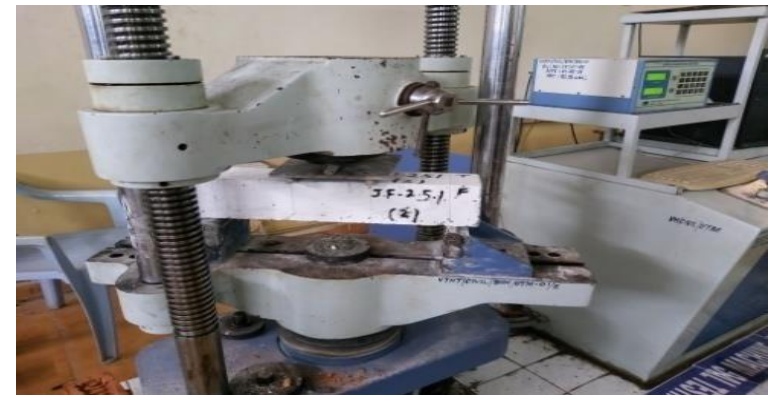

Figure 6 Testing of Flexural beam cast 
The testing was carried out as per Indian standards and the flexural strength is mentioned in the Table 4

Table 4 Flexural sternght of concrete

\begin{tabular}{|c|c|c|c|}
\hline Juliflora & Mix Ratio & Flexural Strength & Percentage of increase \\
\hline JF-0 & $0.0 \%$ & 5.44 & $0 \%$ \\
\hline JF-2.5 & $2.5 \%$ & 6.64 & $122 \%$ \\
\hline JF-5.0 & $5.0 \%$ & 6.41 & $118 \%$ \\
\hline JF-7.5 & $7.5 \%$ & 5.99 & $110 \%$ \\
\hline JF-10.0 & $10.0 \%$ & 5.31 & $98 \%$ \\
\hline
\end{tabular}

From the Table 4 it is seen that there is a increase in the flexural strength of concrete with the replacement of juliflora, also similar to the compressive strength there is a decrease in strength when there is further replacement of juliflora in cement.[6,7]

The relative percentage of increase in the strength with respect to the nominal concrete of juliflora and found to be optimum in $2.5 \%$ replacement. It is observed that there is increase in the JF-2.5 with $122 \%$ increase in strength, while other percentages are relatively less $[6,8]$.

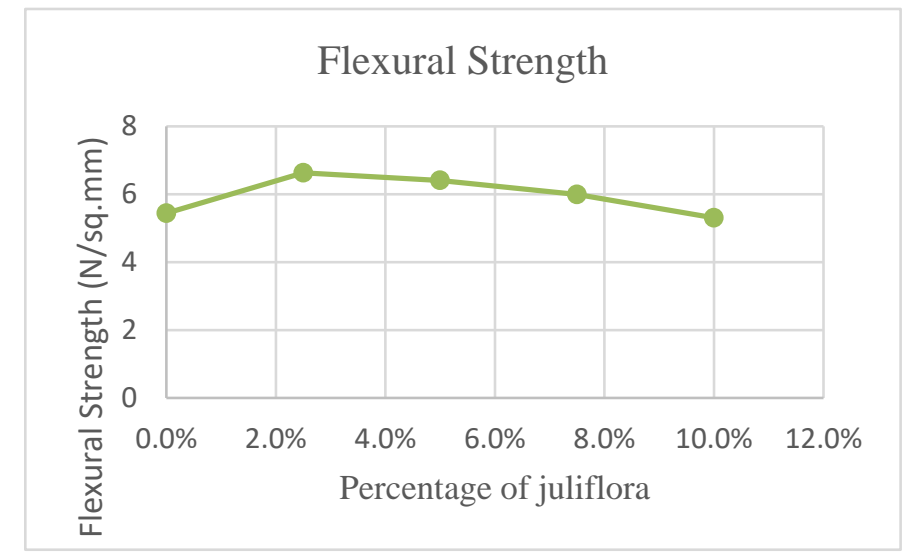

Figure 7 Flexural strength of prsim concrete

Fig 7 shows that there is a increase in the flexural strength by $2.5 \%$ replacement and on further replacement with juliflora there is a decrease in flexural strength.

\section{CONCLUSIONS}

The study focused on determining the effective use of Prosopis juliflora by replacing cement in concrete. With certain percentage of replacement of cement by juliflora the tests were conducted and the results have been noted for comcpression, split tensile and fexural behaviour of concrete. It has been found that on adding a certain percentage of juliflora in concrete had adverse effect in concrete by changing its strength parameter in concrete.

The compressive, split tesile and flexural strength of juliflora concrete was found to be more efficient than the conventional concrete at $2.50 \%$ juliflora ash. Thus, from this study it is found that there is a way to use the juliflora ash in an economical way in concrete to increase the strength of concrete and to reduce the cost of construction. 


\section{REFERENCES}

[1] M.S. Krishna Hygrive, I. Siva Kishore and KJB Chari, Comparative Study on Compressive Strength of Fly Ash Concrete, International Journal of Civil Engineering and Technology, 8 (4), 2017, 1737-1745

[2] Manu S. Nadesan, P. Dinakar, Mix design and properties of fly ash waste lightweight aggregates in structural light weight concrete, Case studies in construction materials,7(4), 2017, 336-347

[3] Ki-Bong Park and Takafumi Noguchi, Effects of Mixing and Curing Temperature on the Strength Development and Pore Structure of Fly Ash Blended Mass Concrete, Advances in Material Science and Engineering, Vol. 6, 2017,1-11.

[4] Mochamad Solikin* and Budi Setiawan, The Effects of Design Strength, Fly Ash Content and Curing Method on Compressive Strength of High Volume Fly Ash Content and Curing Method on Compressive Strength of High Volume Fly Ash Concrete: A Design of Experimental, MATEC Web of Conferences 103, 2017, 01003.

[5] Gopal Paliwal and Savita Maru, Effect of fly ash and plastic waste on mechanical and durability properties of concrete, Advances in Concrete Construction, 5(6), 2017, 575-586.

[6] Raghu k Sharath V.T Naveen, "Experimental Investigation On Partial Replacement Of Cement By Mesquite(Prosopis Juliflora) Wood Ash In Concrete" International Journal for Science Research and Development (IJSRD) Vol 5(6), 2017, 284-287.

[7] A.Durai Murugan, M.Muthuraja, "Experimental Investigation Of Prosopis Juliflora Ash As a Partial Replacement Of Cement In Conventional Concrete " International Journal of Innovative Research in Sceience, Engineering and Technology (IJIRSET) Vol 6(5), 2017, 8285-8293.

[8] P.Packialakshmi ,R.Aasha Jyothi, "Experimental Investigation On Concrete Usimg Hypo Sludge And Wood Ash" International Journsl of Advanced Research (IJAR) 4(4),2016, 1243-1250.

[9] Etavenimadhavi, K .Naveen, D. Naresh, Ch. Chandrasekar, (2016). 'Evaluation Of Wood Ash As Partially Replacement Of Cement' International Journal of Innovative Sceience ,Engineering and Technology(IJISET), 5(4), 2016, 5779-5782.

[10] G.Subbaramaiah,.H.Sudarasan Rao,Vaishali G. Ghorpade, 'Effect Of Addition And Partial Replacement Of Cement By Wood Ash On Strength Properties Of Structural On Grade Concrete' International Journal of Innovative Sceience, Engineering and Technology (IJISET ), 2(9), 2015, 736-743

[11] T. Subramani ,K.S .Ramesh (2015) "Experimental Study On Partial Replacement of Cement With Fly Ash And Complete Replacement Of Sand With M Sand "International Journal of Application or Innovation in Engineering and Management (IJAIEM), 4(5), 2015,.313-322. 